\title{
VOLUME 30 NUMBER 4
}
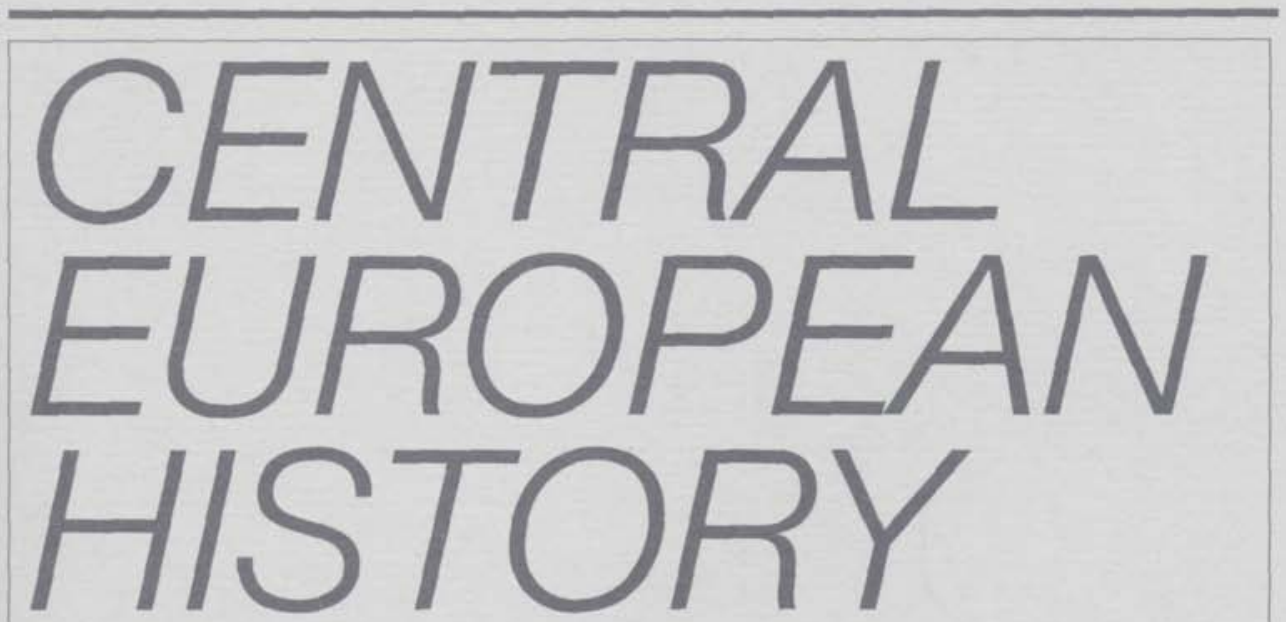

PUiblished by HUMANITIES PRESS INTERNATIONAL, INC. FOR THE CONFERENCE GROUP FOR CENTRAL EUROPEAN HISTORY OF THE AMERICAN HISTORICAL ASSOCIATION

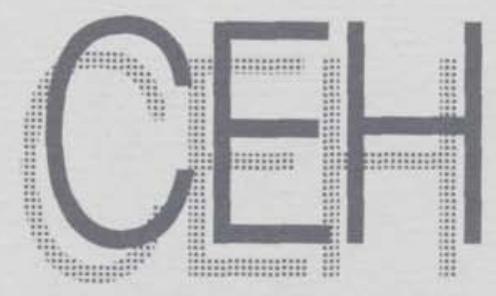




\section{Editorial Policy}

Central European History publishes articles, review articles, book reviews, and conference reports dealing with the history of German-speaking Central Europe. The journal solicits manuscripts using all approaches to history and dealing with all historical periods. Because space is limited, articles which have been or soon will be published elsewhere are not accepted. Manuscripts submitted to CEH should not be under consideration by another journal pending decision of the editor on publication. If it is learned that an article is under submission to another journal while being considered at $\mathrm{CEH}$, consideration will cease immediately. Unsolicited book reviews are not accepted.

Manuscripts and correspondence should be directed to:

\section{The Editor \\ Central European History \\ Department of History \\ University of California, Riverside \\ Riverside, California 92521-0204}

The entire text, including footnotes and headings, of manuscripts submitted for publication must be prepared in double-spaced typescript with generous margins to allow for copyediting. Manuscripts should be submitted in two copies. Footnotes must be numbered consecutively and should be placed in a separate section at the end of the text. It would be very helpful if authors would supply a computer disk with the article, in ASCII text format (MS-DOS) or Word Perfect, on either $31 / 2^{\prime \prime}$ or $51 / 4^{\prime \prime}$ double-sided diskettes.

Further guidelines for the preparation of manuscripts for publication in Central European History will be sent upon acceptance of materials by the editor. All materials will be edited to conform with The Chicago Manual of Style in matters regarding punctuation, capitalization, and format. The final decision on style remains with the editor.

The annual subscription rates for Central European History (4 issues) for the United States are

$\begin{array}{lcc} & \text { INDIVIDUAL } & \text { INSTITUTIONS } \\ 1 \text { Year } & \$ 38.00 & \$ 60.00 \\ 2 \text { Years } & \$ 65.00 & \$ 105.00\end{array}$

These subscriptions are postpaid; for all other countries, add $\$ 10.00$ for mailing. Airmail rates are available on request. Subscriptions are for a full volume year only.

Back issues are available at $\$ 19.95$ each. Volume prices are available on request.

To subscribe, contact your usual subscription agency or Humanities Press International, Inc., 165 First Avenue, Atlantic Highlands, NJ 07716-1289: phone 908-872-1441 or fax 908-872-0717. All payments must be made in U.S. Dollars. Humanities Press accepts checks, Visa, and Mastercard. 


\section{Central European History}

Volume 30

Number 4

\section{ARTICLES}

Shared Lordship, Authority, and Administration:

The Exercise of Dominion in the Gemeine Herrschaften of the Swiss

Confederation, 1417-1600

Randolph C. Head

Challenging Political Culture in Postwar Austria:

Veterans' Associations, Identity, and the

Problem of Contemporary History

Matthew Paul Berg

Kulturkampf and Unification:

German Liberalism and the War Against the Jesuits

Michael B. Gross

\section{REVIEW ARTICLE}

Early Modern Germany in The Encyclopedia of German History,

Part 1, Population, Economics, and the World of the Village

Thomas A. Brady, Jr.

\section{BOOK REVIEWS}

Robert W. Scribner and Trevor Johnson, eds.

Popular Religion in Germany and Central Europe 1400-1800

Philip M. Soergel

Uwe Wilhelm, Der deutsche Frühliberalismus: Von den Anfängen bis 1789 John Christian Laursen

Robert Jütte, Poverty and Deviance in Early Modem Europe 
Geoffrey Wawro, The Austro-Prussian War:

Austria's War with Prussia and Italy in 1866

Arden Bucholz

Mark Roseman, Generations in Conflict:

Youth Revolt and Generation Formation in Germany, 1770-1968 Larry Eugene Jones

Horst Drechsler, Südwestafrika unter deutscher Kolonialherrschaft:

Die grossen Land-und-Minengesellschaften (1885-1914)

Arthur J. Knoll

Gerhard A. Ritter, Arbeiter, Arbeiterbewegung und soziale Ideen

in Deutschland: Beiträge zur Geschichte des 19. und 20. Jahrhunderts

601

Eric D. Weitz

Peter Loewenberg, Fantasy and Reality in History

603

Mitchell G. Ash

Richard W. Rolfs, S. J., The Sorcerer's Apprentice:

The Life of Franz von Papen

George 0. Kent

Henry Cord Meyer, Drang nach Osten:

Fortunes of a Slogan-Concept in German Slavic Relations, 1848-1990 Norman Rich

Jorg Brechtefeld, Mitteleuropa and German Politics: 1848 to the Present Norman Rich

Michael Grüttner, Studenten im Dritten Reich Hermann Beck

Michael H. Kater, The Twisted Muse:

Musicians and Their Music in the Third Reich Alan E. Steinweis

Doris L. Bergen, Twisted Cross:

The German Christian Movement in the Third Reich Richard V. Pierard

Daniela Münkel, Nationalsozialistische Agrarpolitik und Bauernalltag Shelley Baranowski

Gisela Diewald-Kerkman, Politische Denunziation im

NS Regime oder die kleine Macht der "Volksgenossen"

Omer Bartov 
Brigitte Berlekamp and Werner Rohr, eds.,

Terror, Herrschaft und Alltag im Nationalsozialismus:

Problem einer Sozialgeschichte des deutschen Faschismus

Laurence D. Stokes

Rebecca L. Boehling, A Question of Priorities:

Democratic Reform and Democratic Recovery in Postwar Germany:

Frankfurt, Munich, and Stuttgart under U.S. Occupation, 1945-1949

A. J. Nicholls

Günther Bischof and Anton Pelinka, eds.,

Austrian Historical Memory and National Identity

Allan Janik

Patrik von zur Mühlen, Der Eisenberger Kreis:

Jugendwiderstand und Verfolgung in der DDR 1953-1958 John Connelly

Charles S. Maier, Dissolution:

The Crisis of Communism and the End of East Germany

Norman M. Naimark

CONTRIBUTORS TO THIS ISSUE

NEWSLETTER OF THE CONFERENCE GROUP

FOR CENTRAL EUROPEAN HISTORY, SPRING 1998 


\section{Editor \\ Kenneth D. Barkin \\ University of California, Riverside}

Assistant Editor

Ursula Marcum

Celia Applegate

University of Rochester

Volker R. Berghahn

Columbia University

Kees Gispen

University of Mississippi

William W. Hagen

Board of Editors

University of Califomia, Davis

Peter Hayes

Northwestem University

Jonathan Knudsen

Wellesley College

Barbara Miller Lane

Bryn Mawr College

Robert G. Moeller

University of Califomia, Irvine

David Sabean

University of Califormia, Los Angeles

Jonathan Sperber

University of Missouri, Columbia

Central European History is published, four issues per year, by Humanities Press International, Inc. It is indexed or abstracted in Historical Abstracts, Humanities Index, Book Review Index, Internationale Bibliographie der Zeitschriftenliteratur (IBZ), Current Contents/Social and Behavioral Science, Social Science Citation Index, Universal Index System, and Combined Retrospective Index Sets in History (CRIS).

Copyright (C) 1998 by Humanities Press International, Inc. All rights reserved ISSN 0008-9389

Printed in the United States of America 